\title{
STEROID, TRITERPENOID AND PHENYLPROPANOID FROM STEREOSPERMUM SUAVEOLENS (ROXB.) DC GROWING IN BANGLADESH
}

\author{
Md Moniruzzaman, Md Ruhul Kuddus ${ }^{1}$, Md Al Amin Sikder ${ }^{1}$, \\ AM Sarwarudin Chowdhury and Mohammad A RaShid ${ }^{1^{*}}$ \\ Department of Applied Chemistry \& Chemical Engineering, Faculty of Engineering and \\ Technology, University of Dhaka, Dhaka-1000, Bangladesh
}

Keywords: Stigmasterol, $\beta$-amyrin, 4-methoxycinnamic acid, NMR, Stereospermum suaveolens

\begin{abstract}
The study was carried out to investigate the composition of natural compounds of methanol extract of leaf and stem bark of Stereospermum suaveolens (Roxb.) DC by repeated chromatographic separation and purification processes over silica gel. The phytochemical investigation resulted in the isolation of a total of three compounds, which were identified as stigmasterol (1), $\beta$-amyrin (2) and 4-methoxycinnamic acid (3). The chemical structures of the isolated compounds were elucidated by analyses of their physical properties, acquired ${ }^{1} \mathrm{H}$ NMR data and comparison with published reports. Among these, compounds $\mathbf{2}$ and $\mathbf{3}$ are first report of their isolation from this plant species.
\end{abstract}

\section{Introduction}

Stereospermum suaveolens (Roxb.) DC (Family: Bignoniaceae) is a large deciduous plant species that is native to Bangladesh, India and Myanmar. Locally, the plant is familiar as Parul, Atkopali, which grows in the hilly areas of Chattogram, Bangladesh (Ghani 2003). The plant has enormous traditional applications as Ayurvedic medicine to cure various kinds of ailments. The decoction of roots and barks of $S$. suaveolens are beneficial for treatment of inflammations, pain, fevers, asthma, liver disorders etc. (Kirtikar and Basu 1988). The root extract is reported to have anticancer properties (Ramachandran and Mohandoss 1988), whereas flowers blended with honey is used as expectorant (Chopra et al. 1999). Balasubramanian et al. (2009) reported the antihyperglycemic and antioxidant activities of the crude ethanol extract of S. suaveolens bark in preclinical model. Ethyl acetate soluble fraction of ethanol extract of $S$. suaveolens also exhibited similar pharmacological actions (Balasubramanian et al. 2012). A recent study from our laboratory have reported the leaf and stem bark extract of $S$. suaveolens having potential antidiabetic, antidiarrheal and analgesic effects in Swiss Albino mice (Moniruzzaman et al. 2018).

Previous phytochemical studies led to the isolation of lapachol (Joshi et al. 1977), sterekunthal B, stereochenols A and B (Haque et al. 2005 and Haque et al. 2006) from the bark, and scutellarein (Subramanian et al. 1972), stereolensin, dinatin (4,5,7-trihydroxyl-6-methoxyflavon), and dinatin-7-glucuroniside (Ghani 1998) from the leaves of this plant. Begum et al. (Begum et al. 2015) from our phytochemical research laboratory, previously reported fridelin, $\beta$ sitosterone, stigmasterol, 3,4-dimethoxy cis-caffeic acid, 3 $\beta$-friedelanol, $\beta$-amyrone and glyceryl tricaprate from the methanol extract of leaves and bark of $S$. suaveolens.

Since the plant is very significant based on its phytochemical and biological potentials (Chopra et al. 1999), the present study was carried out to isolate and identify the secondary metabolites from this plant. In the present study isolation and characterization of three compounds such as stigmasterol (1), $\beta$-amyrin (2) and 4-methoxycinnamic acid (3) from $S$. suaveolens was carried out.

\footnotetext{
*Author for correspondence: <r.pchem@yahoo.com>. ${ }^{1}$ Phytochemical Research Laboratory, Department of Pharmaceutical Chemistry, Faculty of Pharmacy, University of Dhaka, Dhaka-1000, Bangladesh.
} 


\section{Materials and Methods}

Leaves and stem bark of $S$. suaveolens were collected from Baldha Garden, Wari, Dhaka1100, Bangladesh in October 2015. The plant was authenticated in Bangladesh National Herbarium, Mirpur, Dhaka-1216 where a voucher specimen has been deposited (Accession No. DACB-43522) for future reference. After collection, leaves and stem bark of S. suaveolens were properly cleaned, air dried and ground to a coarse powder using a suitable grinding machine at the laboratory of Department of Applied Chemistry and Chemical Engineering, University of Dhaka, Dhaka-1000, Bangladesh. About 350g of powdered materials of leaves and stem bark was taken in a round bottom flask and soaked in 2.51 of methanol for several days with occasional shaking and stirring. The mixture was filtered through a fresh cotton plug and finally with a Whatman filter paper Number 1 . The filtrate was concentrated using a rotary evaporator at $40{ }^{\circ} \mathrm{C}$ under reduced pressure. The gummy concentrate $(10 \mathrm{~g})$ obtained was designated as crude methanolic extract of leaves of $S$. suaveolens. About $5 \mathrm{~g}$ of the crude extract was subjected to solvent-solvent partitioning according to the modified Kupchan method (VanWagenen et al. 1993) to yield $n$ hexane, carbon tetrachloride, chloroform and aqueous soluble fractions.

NMR spectra of the isolated compounds were acquired in $\mathrm{CDCl}_{3}$ using a Bruker AMX-400 (400 MHz) instrument in Wazed Miah Science Research Centre (WMSRC), Jahangirnagar University, Savar, Bangladesh. The spectra were referenced to the residual nondeuterated solvent signal. Preparative thin layer chromatography (PTLC) was performed on pre-coated plates (TLC Silica gel $60 \mathrm{~F}_{254}$ ) for purification of compounds. Pure compounds on TLC and PTLC plates were visualized by spraying with vanillin-sulfuric acid followed by heating for 5 min at $110{ }^{\circ} \mathrm{C}$. All other chemicals, solvents and spray reagents were of analytical grade.

For separation, both $n$-hexane and carbon tetrachloride soluble paritionates of methanol extract of leaves and stem bark of S. suaveolens were fractionated separately by gel permeation chromatography using lipophilic Sephadex (LH-20). About 25 fractions of each $10 \mathrm{ml}$ were obtained separately from both $n$-hexane and carbon tetrachloride soluble partitionates. Repeated preparative TLC of sub-fraction 7-9 of $n$-hexane soluble fraction over silica gel using dichloromethane: hexane (50:50) provided compound 1, while sub-fraction 18-25 gave compound 2 by using mixture of ethyl acetate and toluene (20:80) as mobile phase. On the other hand, purification of sub-fractions 17-19 from carbon tetrachloride soluble fraction over silica gel using mobile phase consisting of ethyl acetate and toluene (40:60) afforded compound 3 . Properties of isolated compounds are:

Stigmasterol (1): White crystalline powder; ${ }^{1} \mathrm{H}$ NMR $\left(400 \mathrm{MHz}, \mathrm{CDCl}_{3}\right): \delta 0.71(3 \mathrm{H}, \mathrm{s}, \mathrm{Me}-$ 10), 0.82 and 0.85 (each $\left.3 \mathrm{H}, \mathrm{d}, J=7.2 \mathrm{~Hz}, \mathrm{Me}_{2}-25\right), 0.93(3 \mathrm{H}, \mathrm{d}, J=6.4 \mathrm{~Hz}, \mathrm{Me}-20), 0.97(3 \mathrm{H}, \mathrm{t}$, $J=6.8 \mathrm{~Hz}, \mathrm{Me}-28), 1.03(3 \mathrm{H}, \mathrm{s}, \mathrm{Me}-13), 3.54(1 \mathrm{H}, \mathrm{m}, \mathrm{H}-3), 5.03(1 \mathrm{H}, \mathrm{dd}, J=15.2,8.4, \mathrm{~Hz}, \mathrm{H}-$ 23), $5.15(1 \mathrm{H}, \mathrm{dd}, J=15.2,8.4 \mathrm{~Hz}, \mathrm{H}-22), 5.31(1 \mathrm{H}, \mathrm{t}, J=4.8 \mathrm{~Hz}, \mathrm{H}-6)$.

$\beta$-amyrin (2): (Syn. Olean-12-en-3 $\beta$-ol); Yellowish white powder; ${ }^{1} \mathrm{H}$ NMR (400 MHz, $\left.\mathrm{CDCl}_{3}\right): 0.75(3 \mathrm{H}, \mathrm{s}, \mathrm{Me}-24), 0.79$ (3H, s, Me-28), 0.90 (3H, s, Me-29), 0.90 (3H, s, Me-30), 0.94 $(3 \mathrm{H}, \mathrm{s}, \mathrm{Me}-25), 0.95(3 \mathrm{H}, \mathrm{s}, \mathrm{Me}-23), 1.10(3 \mathrm{H}, \mathrm{s}, \mathrm{Me}-26), 1.23(3 \mathrm{H}, \mathrm{s}, \mathrm{Me}-27), 3.20(1 \mathrm{H}, \mathrm{dd}, J=$ $\left.11.5,3.5 \mathrm{~Hz}, \mathrm{H}_{3}\right), 5.21(1 \mathrm{H}, \mathrm{t}, J=3.5 \mathrm{~Hz}, \mathrm{H}-12)$.

4-Methoxycinnamic acid (3): White crystal; ${ }^{1} \mathrm{H}$ NMR $\left(400 \mathrm{MHz}, \mathrm{CDCl}_{3}\right): \delta 3.87(3 \mathrm{H}, \mathrm{s}, 4-$ OMe), $6.34(1 \mathrm{H}, \mathrm{d}, J=16.0 \mathrm{~Hz}, \mathrm{H}-8), 6.95(2 \mathrm{H}, \mathrm{d}, J=8.0 \mathrm{~Hz}, \mathrm{H}-3, \mathrm{H}-5), 7.53(2 \mathrm{H}, \mathrm{d}, J=8.0 \mathrm{~Hz}$, $\mathrm{H}-2, \mathrm{H}-6), 7.76(1 \mathrm{H}, \mathrm{d}, J=16.0 \mathrm{~Hz}, \mathrm{H}-7)$.

\section{Results and Discussion}

The ${ }^{1} \mathrm{H}$ NMR spectrum of compound $\mathbf{1}$ (Fig. 1) suggested a steroidal compound. Comparison of its spectrum with that of stigmasterol (Sufian et al. 2011) and co-TLC with the authentic sample confirmed the identity of compound $\mathbf{1}$ as stigmasterol. 


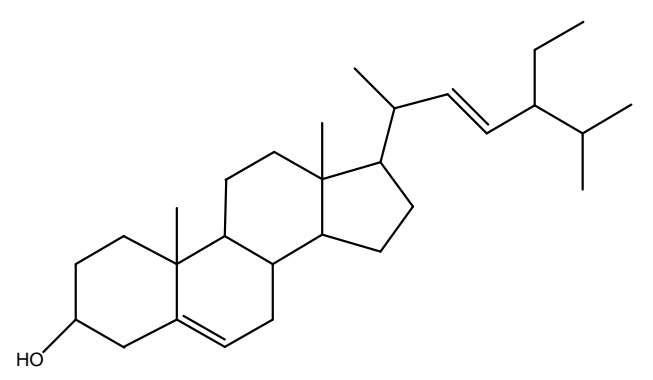

Stigmasterol (1)

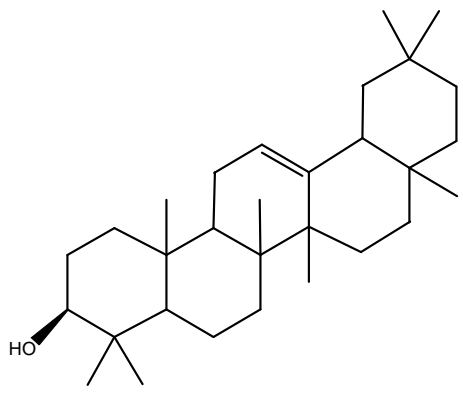

$\beta$-amyrin (2)<smiles>COc1ccc(/C=C/C(=O)O)cc1</smiles>

4-methoxycinnamic acid (3)

Fig. 1. Compounds isolated from S. suaveolens.

The ${ }^{1} \mathrm{H}$ NMR spectrum of compound 2 (Fig. 1) showed a one proton triplet $(J=3.5 \mathrm{~Hz})$ at $\delta$ 5.21 for an olefinic proton (H-12) of an olean-12-ene-type carbon skeleton (Kuddus et al. 2011). The ${ }^{1} \mathrm{H}$ NMR spectrum also revealed a double doublet $(1 \mathrm{H}, \mathrm{d}, J=11.5,3.5 \mathrm{~Hz}, \mathrm{H}-3)$ of one proton intensity centered at $\delta 3.20$, which is indicative of the typical oxymethine proton at C-3 of the pentacyclic triterpene nucleus. The spectrum further demonstrated the presence of eight singlets of three protons intensity at $\delta 0.75,0.79,0.90(6 \mathrm{H}), 0.94,0.95,1.10,1.23$ which could be assigned to $\mathrm{H}_{3}-24, \mathrm{H}_{3}-28, \mathrm{H}_{3}-29, \mathrm{H}_{3}-30, \mathrm{H}_{3}-25, \mathrm{H}_{3}-23, \mathrm{H}_{3}-26, \mathrm{H}_{3}-27$, respectively of an oleanane type triterpene. The above spectral features are in close agreement to those observed for $\beta$-amyrin (Ahmed et al. 2015). Thus, the structure of compound $\mathbf{2}$ was solved as $\beta$-amyrin. The identity of this compound was further confirmed by direct comparison of its ${ }^{1} \mathrm{H}$ NMR spectrum with previously acquired ${ }^{1} \mathrm{H}$ NMR spectrum of $\beta$-amyrin as well as previously reported values (Ahmed et al. 2015).

The ${ }^{1} \mathrm{H}$ NMR spectrum of compound 3 (Fig. 1) displayed two doublets $(J=8.0 \mathrm{~Hz})$ centered at $\delta 6.95(\mathrm{H}-3 / \mathrm{H}-5)$ and $7.53(\mathrm{H}-2 / \mathrm{H}-6)$, each integrating for two protons. The splitting pattern and coupling constants of the aromatic protons indicated the presence of 1,4-disubstituted benzene ring (Kuddus et al. 2010a). Two additional doublets $(J=16.0 \mathrm{~Hz})$ at $\delta 7.76$ and $\delta 6.34$ confirmed the presence of a pair of trans-coupled olefinic protons at $\mathrm{H}-7$ and $\mathrm{H}-8$, respectively. The spectrum also showed a singlet of three protons intensity at $\delta 3.87$ demonstrative of a methoxy group at C-4 position of the aromatic ring. The above spectral features are in close agreement with those results observed for 4-methoxycinnamic acid (Kuddus et al. 2010a and b). On this basis, compound 3 was characterized as 4-methoxycinnamic acid.

Phytochemical investigation of $n$-hexane and carbon tetrachloride soluble fractions of a methanol extract of leaf and stem bark of $S$. suaveolens yielded three compounds, which were characterized as stigmasterol (1), $\beta$-amyrin (2) and 4-methoxycinnamic acid (3) on the basis of their spectral data. These compounds are known compounds and their bioactivities are also well known. However, further studies are needed to isolate more potential bioactive compounds from the plant to correlate the traditional uses of the plant. 


\section{References}

Ahmed I, Islam R, Sikder MA, Haque MR, Al Mansur MA and Rashid MA 2015. Alkaloid, sterol and triterpenoids from Glycosmis pentaphylla (Retz.) DC. Dhaka Univ. J. Pharm. Sci. 13(2): 115-118.

Balasubramanian T, Chatterjee TK, Senthilkumar GP and Mani T 2012. Effect of potent ethyl acetate fraction of Stereospermum suaveolens extract in streptozotocin-induced diabetic rats. Sci. World J. 2012: Article ID 413196. https://doi.org/10.1100/2012/413196.

Balasubramanian T, Lal MS, Sarkar M and Chatterjee TK 2009. Antihyperglycemic and antioxidant activities of medicinal plant Stereospermum suaveolens in streptozotocin-induced diabetic rats. J. Diet. Suppl. 6(3): 227-251.

Begum F, Haque MR, Nahar K and Rashid MA 2015. Secondary metabolites from different extractives of Stereospermum suaveolens. Dhaka Univ. J. Pharm. Sci. 13(1): 31-36.

Chopra RN, Nayar SL and Chopra IC 1999. Glossary of Indian Medicinal Plants, National Institute of Science Communication, CSIR, New Delhi, India, 1999.

Ghani A 2003. Medicinal Plants of Bangladesh: Chemical Constituents and Uses (2 ${ }^{\text {nd }}$ Edition), pp. 1-16. Asiatic Society of Bangladesh, Dhaka-1000, Bangladesh.

Ghani A 1998. Medicinal Plants of Bangladesh: Chemical Constituents and Uses ( ${ }^{\text {st }}$ Edition), Asiatic Society of Bangladesh, Dhaka-1000, Bangladesh.

Haque MR, Rahman KM, Begum B, Hasan CM and Rashid MA 2005. Secondary metabolites from Stereospermum chelonoides. Dhaka Univ. J. Pharm. Sci. 4: 61-64.

Haque MR, Rahman KM, Begum B, Iskander MN, Hasan CM and Rashid MA 2006. Stereochenols A and B, two quinones from Stereospermum chelonoides. Phytochemistry 67(24): 2663-2665.

Joshi KC, Bansal RK and Patni R 1977. Chemical examination of the roots of Stereospermum suaveolens DC. J. Indian Chem. Soc. 54(6): 648-649.

Kirtikar KR and Basu BD 1988. Indian Medicinal Plants, International Book Distributors, Dehradun, India.

Kuddus MR, Rumi F, Kaisar MA, and Hasan CM 2010a. Sesquiterpene and phenylpropanoids from Curcuma longa. Bangladesh Pharm. J. 13(2): 31-34.

Kuddus MR, Rumi F, Kaisar MA, Hasan CM and Rashid MA 2010b. Trans-isoferulic acid from Curcuma longa. Bol. Latinoam. Caribe. Plant Med. Aromat. 9(4): 319-321.

Kuddus MR, Rumi R, Kaisar MA, Rahman MS, Hasan CM, Hassan MA and Rashid MA 2011. Secondary metabolites from Melocanna baccifera (Roxb.). Asian J. Chem. 23(1): 85-88.

Moniruzzaman M, Kuddus MR, Haque MR, Chowdhury A and Rashid MA 2018. Stereospermum suaveolens (Roxb.) DC. shows potential in vivo and in vitro bioactivities. Dhaka Univ. J. Pharm. Sci. 17(2): 257263.

Ramachandran G and Mohandoss S 1988. 6-O-B-D-Glucosyl scutellarein-a rare flavone glycoside from Stereospermum suaveolens. J. Indian Chem. Soc. 65(2): 150-151.

Subramanian S, Sankara S, Nagarajan and Sulochana N 1972. Flavonoids of the leaves of Stereospermum suaveolens. Curr. Sci. 41(3): 102-103.

Sufian MA, Begum F, Haque MR, Hasan CM and Rashid MA 2015. Sterol and triterpenoids from Hygrophila schulli Buch-Ham. Bangladesh J. Bot. 44: 319-321.

VanWagenen BC, Larsen R, Cardellina JHII, Randazzo D, Lidert ZC, and Swithenbank C 1993. Ulosantoin, a potent insecticide from the sponge Ulosa reutzleri. J. Org. Chem. 58: 335-337. 